\title{
Chinese-style Pragmatic Objectivity in War Reporting
}

\author{
Shixin Ivy Zhang \\ School of International Communications, University of Nottingham Ningbo China
}

\begin{abstract}
China plays an increasing role in the wars and conflicts around the world with its expanding political and economic interests overseas, and its diplomatic role in international affairs. More and more Chinese journalists go to the frontlines overseas to cover distant conflicts for domestic audiences. Based on semi-structured in-depth interviews with sixteen Chinese correspondents who have covered conflicts outside China, this study examines Chinese journalists' perceptions and reflections on objectivity in the war zones. The author adopts a term of Chinese-style pragmatic objectivity to mean that objectivity is a convenient approach for Chinese journalists to do war journalism in the field. At the level of objectivity-as-avalue, objectivity is defined as a pragmatic value and a practical ritual for Chinese journalists to do news within the scope they can reach, to protect themselves from criticisms, and to justify their version of the truth. It promotes allegiance and patriotism. At the level of objectivity-as-a-practice, objectivity in war coverage is compromised by China's foreign policies, military constraints, the press's political orientations and editorial polices, and journalists' personal experiences and values. Chinese journalists use Chinese-style objectivity to negotiate their roles in the power struggle with the state, foreign militaries, the newsroom and journalists.
\end{abstract}

Key words: China; war correspondents; objectivity; constraints 


\section{Introduction}

Today many journalists, often numbering in the thousands, congregate in war zones. They come from many different places, transmit information via satellite with unprecedented speed, and inform the widest audiences of trouble spots and developing crises. In addition, the freedom of media, the right of journalists to be present as witnesses in conflicts, is a key aspect of the emergent consciousness of global citizenship (Tumber \& Webster, 2006).

Chinese journalists are an emerging force active in today's war zones. They are no longer simply translating the wires from western news agencies. With China's expanding political and economic interests overseas and its increasing diplomatic role in international affairs, more and more Chinese journalists go to the frontlines overseas to cover distant conflicts for domestic audiences.

From 1990s, Chinese journalists have been posted overseas to cover news from the international hotspots for conflicts such as Iraq, Afghanistan, Kosovo, Israel, Palestine, Libya, and Syria. In these wars and conflicts, although China was not a participant country and it did not involve China directly, Chinese correspondents entered the war zones and filed reports back to China. Taking the Libyan war in 2011 as an example, approximately 30 to 40 Chinese journalists were present (personal communication, 2012). Chinese language TV media "made a collective debut on the world's battle field" ('Chinese war correspondents in Libya', 2011). News organisations including China Central Television Station (CCTV), Dragon TV in Shanghai and Phoenix Satellite TV in Hong Kong sent reporters to the front lines. CCTV dispatched a total of 16 correspondents to report from the frontline and filed more than 1,000 news pieces back home (ibid). Commercialized newspapers such as Global Times - a spin-off tabloid under the umbrella of People's Daily - Southern Weekend, and Southern Metropolis Daily also assigned journalists to bring news reports back from Libya.

In a transitional society like China that is shifting from a centrally planned economy to a market driven economy, media have gained economic autonomy but they have not earned a corresponding degree of editorial or political autonomy (Hadland \& Zhang, 2012). Chinese news media remain state owned and Chinese journalists are semi-governmental officials ( $\mathrm{Wu}$, 2000). When it comes to conflict coverage, Chinese war correspondents are meant "to propagate policies, to boost morale, to unite the masses and to fight against enemies. They emphasize publicity on the basis of objective reporting" (Zhao, 2007, p.104).

Meanwhile, news professionalism as the normative model of journalism is on the rise in China. The reforms are eroding the party-press ideology and could potentially elevate the canons of journalistic professionalism, such as objectivity and press freedom (Pan \& Chan, 2003). Objectivity and balance have become main news values and ideologies to Chinese journalists among other values such as timeliness, uncovering the truth, recording history, national interests and social responsibility. For example, Liu Qian of CCTV claims, "the most important principle for news is objectivity, and then immediacy. Our job is to inform.

National interest and social stability are also important" (Polumbaum, 2008, p. 152). "I think the fundamental tenets are the same everywhere: accuracy, objectivity, timeliness, such basic requirements. Furthermore, you must have your own values," said Liu Zhouwei of $21^{\text {st }}$ Century Business Herald (ibid). As for wartime journalism, Chinese journalists claim to have adopted a Western model of objective reporting to a certain extent. Zhang (2013) finds that Chinese war correspondents perceive their complex mix of roles as objective reporter, interpreter, propagandist and diplomat. Their main job is to bring facts from the frontline and 
explain the origins, causes, occurrences and effects of the conflicts to Chinese audiences and decision makers. Like their western counterparts, Chinese war correspondents also emphasize "facts", "balance" and a "neutral stand" (ibid). Liang (2011) finds that in the Iraq War, Chinese news media such as CCTV international channel have changed their news format and applied news values such as "balanced reporting".

However professionalism as an ideology is truncated and fragmented in China (Pan \& Lu, 2003, p. 230). The ways in which ideas such as objectivity manifest in practices are strictly local since these ideas are mixed with other discourses including Party press, Confucian intellectuals and the market economy. "Under the political and economic conditions of the reforms, China's journalists cannot and do not approach their work with fixed conceptual categories derived from a universal model" (ibid). But how ideas such as objectivity are perceived and implemented by Chinese journalists remains a question.

This study intends to examine Chinese journalists' perceptions and reflections towards objectivity in their war coverage. It addresses two questions: 1) How do Chinese war correspondents perceive the concept of objectivity? 2) What are the constraints and obstacles that compromise objectivity in their war coverage?

The question of Chinese journalists' perceptions of professional journalism remains a mystery to scholars who are interested in journalistic standards and practices. There is little found in the English language literature that can shine a light on today's Chinese war correspondents and their norms and practices. This study thus fills the gap in the professional journalism literature and uncovers Chinese journalists' perceptions and realizations of objectivity, thereby contributing to existing knowledge from a non-Western perspective.

\section{Objectivity in wartime journalism}

The concept of objectivity has been regarded as a cornerstone principle of journalism since the 19th century. Although objectivity has been contested widely among scholars, it still remains firmly entrenched when it comes to setting up professional criteria in public debates (Muñoz-Torres, 2012). The origin, evolution and philosophical underpinning of the concept of objectivity are beyond the scope of this paper. This study adopts Carpentier and Trioen's (2010) theoretical framework on the particularity of objectivity to discuss wartime journalism from Chinese perspectives.

Carpentier and Trioen (2010) proposed that objectivity is constructed at two levels on the basis of Laclau's approach to universalism and particularism: first, objectivity is considered as a universalized and hegemonized value and a nodal point of "good journalism"; second, objectivity is always imperfect at the level of practice. The particularity of objectivity creates a gap between journalistic ideology and practice.

At the first level of objectivity-as-a-value, there is still need for objectivity in contemporary journalism and objectivity is fixed as the only form of "good" journalism (Carpentier and Trioen, 2010). Objectivity is defined as a norm that signifies detachment and neutrality.

"Objectivity guides journalists to separate facts from values and to report only the facts. Objective reporting is supposed to be cool, rather than emotional, in tone. Objective reporting takes pains to represent fairly each leading side in a political controversy. According to the objectivity norm, the journalist's job consists of 
reporting something called 'news' without commenting on it, slanting it, or shaping its formulation in any way." (Schudson, 2001, p. 150)

Although Schudson's definition of objectivity is commonly accepted, objectivity is regarded as an ambiguous term and the articulation of the objectivity concept is regarded as problematic. Critics have pointed out that the problems are in relation to realist and empiricist thought. The premises for achieving objectivity is that there is such a thing as objective reality out there and journalists reflect reality as "simply a given set of facts" (Hackett, 1984, p. 236), as "an account of something real" (Campbell and Wolseley, 1961, p. 6) or as something that 'has actually happened' (Harris et al., 1981, p. 27). However, many academics and journalists problematize the status of objectivity. They think it is impossible to achieve value-free neutrality. "The concept of objectivity has been viewed as inauthentic and illusory, masking a deeper ideological subjectivity linked to the maintenance of elite interests" (McNair, 2013, p. 84). Objectivity has been dismissed not only as an unattainable standard but also as an undesirable norm (Boudana, 2011). Other synonymous concepts like 'fairness', "balance", "accuracy", "detachment", "impartiality" or "truth" are used to define and (re-) legitimize media practitioners' practices (Deuze, 2005; Bennette, 2003; Tumber \& Prentoulis, 2003; Boudana, 2010)

On the other side of the debate, scholars (Schudson, 1978; Gans, 1979) argue that objectivity emerged and developed as a means of attaining journalistic credibility. Objectivity may not be possible but that does not mean one should not strive for it, or redefine it in such a way that it in fact becomes possible (Ryan, 2001). It shall be seen as a moral ideal that legitimizes the journalistic profession (Schudson, 1978), as a performance of the techniques of sourcing and processing information (McNair, 2013, p. 84), and as a strategic ritual that journalists use to protect them from mistakes and critics (Tuchman, 1972). Objective journalism does not imply neutral, value-free or impartial journalism but rather signals an honest attempt has been made to ensure a trusted source for accurate information in the news (McNair, 2013, p. 84).

Academics seem to be stuck in between giving objectivity a burial and retaining objectivity. Scholars such as Geneva Overholser of the Missouri School of Journalism denounced objectivity as "worse than useless" and called for "a forthright jettisoning of the objectivity credo" (Berry, 2005), whereas Stephen J. Berry called for reclaiming objectivity since "objectivity is a standard that requires journalists to try to put aside emotions and prejudices, including those implanted by the spinners and manipulators ... Rather than cower to those who would use objectivity as a cudgel against us, we should reclaim it, use it, and reveal how we pursue it." (ibid)

To break the impasse surrounding journalistic objectivity, Ward proposed the concept of pragmatic objectivity that goes beyond the fact/value dualism. Pragmatic objectivity is a normative theory set forth in Stephen Ward (2004)'s The Invention of Journalism Ethics. As an epistemic evaluation of truth-seeking inquiry in journalism, pragmatic objectivity is "a holistic, fallible, rational evaluation of reports" (Ward, 2004, p. 300). Unlike the traditional objectivity that champions a perfect objectivity and emphasizes norms of neutrality and detachment, pragmatic objectivity realises the imperfection of objectivity and focuses on "interpretation", "conceptual scheme", and "holistic evaluation". Specifically, it draws our attention to "the degree of objectivity of a specific report" (Ward, 2004. p. 314) and the possibility of measuring whether a report is pragmatically objective by "empirical standards, coherence standards, and standards of rational debate" (Ward, 2004, p. 297). Pragmatic 
objectivity does not deny traditional objectivity and it gives much flexibility and leeway to evaluate journalism objectivity as a norm. However as Ward acknowledges, it only offers a philosophical framework for understanding the evolution of journalism ethics and the concept of objectivity (Ward, 2004, p. 331). How pragmatic objectivity plays out in practice remains an issue. The present study will use the concept of pragmatic objectivity to discuss the empirical data drawn from Chinese war reporting.

When it comes to wartime journalism, objectivity as a value is still relevant and debated in relation to three main themes: the unattainability of objectivity, attachment of journalism and contextual objectivity.

First, objectivity is rejected as a standard or a norm. Although scholars such as McLaughlin (2002, p. 153) argued that objectivity has informed its practice and legitimation as a neutral medium of information even in the midst of battle, the general view is that it is difficult and nearly impossible for journalists to be a "neutral observer" or "bystander" especially during wartime. In wartime, there are always complex relations between journalism and patriotism in which objectivity and conventional journalistic standards are often skewed to serve partisan ends (Kellner, 2008). Boudana (2010) interviewed 13 French war correspondents about their guiding values and concludes that objectivity is rejected as either an unattainable standard or an undesirable norm. Instead most journalists take accuracy and fairness as criteria to evaluate journalistic performance. Hampton (2008) finds that British journalists never accepted objectivity as a generalized ideal. Ideals such as independence, fair play, and non-intervention by the state were far more compelling than objectivity.

Second, journalism of attachment replaces detachment. In modern conflicts immediately before and after the turn of the $21^{\text {st }}$ century, the Balkans in particular, Western journalists under moral and humanitarian pressures began to reassess the guiding principle of objectivity and detachment. Martin Bell of BBC criticizes the tenets of objective and impartial reporting and "bystander" journalism represented by "distance and detachment". He argued for "journalism of attachment" which means "a journalism that cares as well as knows; that is aware of its responsibilities; that will not stand neutrally between good and evil, right and wrong, the victim and the oppressor" (Williams, 2011, p. 14). In response to Bell's argument, Ward (1998) attempts to adopt a centrist position between the concept of objectivity and journalism of attachment. He claims that "a narrow standard of objectivity that allows 'only facts' in reports is useless for much of journalism. But a journalism of attachment that stresses feelings, value judgement, and interpretations is reckless without objectivity. What is needed is a flexible standard of objectivity" (Ward, 1998, p. 124, cited in Spencer, 2005, pp. 98-99).

Third, contextual objectivity emerged in early 2000s as a novel approach to reconcile the implausibility of objectivity as a rational ideal and the journalism's responsibility to the public (Iskankar, 2005, p. 164). Iskandar and El-Nawawy (2004) borrowed from quantum mechanics and proposed the concept of "contextual objectivity" to describe Al-jazeera's war coverage by balancing the tension between audience appeal and "objective" coverage. Contextualization means creating collectivism among participants within the same cultural, religious, political, and economic context. This contextualization "complicates the pursuit of even-handed coverage and is capable of speaking to the 'enemy' at times of war" (ElNawawy \& Iskandar, 2002). In other words, all news channels offer their viewers 
comprehensive and selective information that reflects the viewers' interests. They are all contextually objective to one extent or another (Berenger, 2005). Al-Jazeera is a good examples in practising contextual objectivity. However critics argue that the term of contextual objectivity is a dubious notion, "at best a muddle, at worst, an evasion' and it is used to 'defend Al Jazeera from its detractors" (El-Nawawy \& Iskandar, 2002).

Objectivity, as an ideological construct and contentious journalistic value, standard and norm, is still valid and relevant in contemporary wartime journalism. Rather than simply equating objectivity with detachment and neutrality, the concept of objectivity has been explained, contested and expanded in multiple perspectives ranging from using other terms to re-define or replace objectivity (e.g. accuracy and fairness, pragmatic objectivity), adding moral and ethical responsibility to the objectivity norm (e.g. journalism of attachment), and putting objectivity in a particular context and culture to make news credible to the targeted audiences (e.g. contextual objectivity). After all, in the post 9/11 era, we are witnessing a paradigmatic shift from detachment to involvement, from verification to assertion, from objectivity to subjectivity (Tumber and Prentoulis, 2003, p. 228).

At the second level of objectivity-as-a-practice, the tension between the concept and its realization generates a paradox: on the one hand, journalistic practice needs the objectivity concept because it provides the journalistic identity with coherence and meaning; on the other hand, the meaning of objectivity does not coincide with journalists' imperfect practices. There is a gap between what journalists want to do and what they actually do (Carpentier and Trioen, 2010). Four major obstacles are often cited in the literature as hindering the realization of objectivity: political bias, organizational and structural constraints, problems posed by the social (re)construction of reality, and the barrier of language (Boudana, 2011).

In wartime, the tenet of objectivity is compromised by allegiance, access and censorship (Anderson \&Trembath, 2011, p. 300). War correspondents under military constraints are no longer heralded as heroes (Knightley, 2002). Such constraints are more obvious to the embedded journalists. The debate about the roles of embedded journalists in the 2003 Iraq War reflects the dilemma war correspondents face. On the one hand, supporters argued that embedded reporting allowed first-hand reports in real time. Yet critics argued that journalists could not report objectively when they depended on the military for their needs and safety (Fahmy \& Johnson, 2005).

Lastly, there are different forms of journalism including conventions, practice and values in different cultures. A cross-cultural analysis of television coverage of the 2003 Iraq War finds that objectivity is defined in large part by culture and ideology more than events (Aday, Livingston \& Hebert, 2005). While objectivity might be operationalized within a two-party political system, it is 'almost impossible within an intricate and fragmented panorama in which a greater number of political forces act' (Mancini, 2000, p. 273). The MacBride Report (1980) also drew attention to the problems of performing objective journalism in a highly politicized society. It emphasized that the wide dissemination of the US model made it difficult for any journalists to advocate practices that violate principles of autonomy and private ownership (Williams, 2011, p. 44). Chinese journalists often talk about "objectivity" and/or "objective reporting". They seem to have adopted the idea of objectivity from American journalism. But what objectivity means to them, how they realise and practise objectivity, in other words, how they localize objectivity in their work remain unanswered. 
This study applies the two levels of objectivity: objectivity-as-a-value and objectivity-as-apractice to address the following research questions:

RQ1: How do Chinese war correspondents perceive the concept of objectivity?

RQ2: What are the constraints and obstacles that compromise objectivity in Chinese war correspondents' coverage?

\section{Research methods}

This study uses qualitative analysis based on semi-structured in-depth interviews with a total of 16 Chinese journalists who have been to conflict/war zones overseas ranging from Israel \& Palestinian, Iraq, Afghanistan, Kosovo, Haiti, East Timor, Pakistan, to Libya and Syria.

In this study, Chinese war correspondents are defined broadly as the Chinese journalists who have been to overseas conflict zones at least once and covered stories about the region for their news organisations. The author conducted field work in Beijing and Ningbo from 1 July to 1 September 2012. She did seven face-to-face interviews, seven phone interviews, one interview via Skype, and one via email. On average, each interview lasted one hour. The purpose is to find out Chinese journalists' perceptions and attitudes towards objectivity, constraints and obstacles in their war/conflict coverage. All interviews were transcribed manually by the author. Pseudonyms are given to each interviewee and interviewees' affiliations are unidentified.

In order to collect data from a wide geographical area and media spectrum, the interviewees were selected from two cities: Beijing and Guangzhou, the press centres in North and South China respectively. Interviewees are practising journalists and editors who work at commercialized newspapers, state and commercial TV stations and state news agency. Interviewees are from Global Times (English and Chinese versions); Beijing Youth Daily; Southern Weekend, Southern Metropolis Daily; Phoenix TV (commercial TV station based in Hong Kong); CCTV (state TV station) and state Xinhua news agency.

This study uses the snowball sampling method. The author worked for Beijing Today, an English weekly affiliated to Beijing Youth Daily as a journalist for two years from 2001 to 2003. She also worked for the English version of Global Times as the International News Editor from March to May 2009. She has contacts at these two newspapers. Her contacts and personal friends introduced other reporters for interviews.

\section{Objectivity-as-a-value}

Chinese journalists perceive objectivity as a journalistic ideal and a guiding principle in their war reporting along with other values such as independence, balance, comprehensiveness and upholding state interests. Most interviewees take objective reporting as their primary role in the coverage of inter-state conflicts. Objectivity is regarded as a universal professional ethic despite geographical locations, nation-states, or news genres. "The job of all journalists is to do objective reporting no matter whether they cover the wars or domestic news. This is professional ethics. As a reporter, our job is to report the event as it is," said Charlie.

(Personal communication, 2012) 
Although most interviewees take objectivity as their main value in covering wars and conflicts, the meaning of objectivity varied with different people. It can mean facts, detachment, neutrality, diversification of news sources, balance and the truth. Journalists often use these terms interchangeably when talking about objectivity.

Objectivity means facts, detachment and neutrality. To some interviewees, objectivity implies covering the facts they witness in the warring states and passing on the information directly to the domestic audience back in China. China is a third country that does not participate in the conflicts overseas. In addition, China does not normally actively or overtly assert its influence in armed conflicts. Chinese journalists had limited knowledge, contacts, resources and physical energy in the region. All these factors justify Chinese journalists' role as observers and their neutral position rather than being critical or being participants. For instance, interviewees claim, "We need to transmit the information objectively. After we arrived (in Libya), we would cover the situations there in a timely and objective manner. We also want to dig deep and reveal the impacts the war has had on the country and the individuals"; "I hope we can, as an observer, look at local happenings and local people's minds and feelings"; "We are objective in details. Due to our limited resources and physical ability, we can only report what we see on the spot at a particular point of time". One correspondent Bob thinks objectivity is even more important to Chinese journalists than to their Western counterparts. He said the only thing Chinese journalists are able to do is to go to the war field and report the facts.

"We are not strong enough to criticize other countries, or to participate. I believe the European and American journalists are in a position to play the role of participant. (In Libya), I know a French journalist in Benghazi. He introduced the leadership of Libyan opposition party to Sarkozy (the then French prime minister). Then through Sarkozy, the opposition party knew Hillary (Clinton). He (the French journalist) changed the entire political landscape. Chinese journalists have not come this far. We don't have the influence or the power to intervene other countries' affairs. We report facts to enable people back home to understand the real situation and provide references for decision makers," said Bob. (Personal communication, 2012)

To Chinese war correspondents, the rationale behind their adoption of objectivity as their guiding principle is three-fold: First, China is not a participant country in the conflicts overseas; Second, China does not actively assert its influence in armed conflicts or play a deciding role in regional conflicts; Third, Chinese correspondents are not capable of playing critical and participant roles due to their limited knowledge and resources. Thus objectivity is a pragmatic value that Chinese war correspondents can actually use and apply.

Objectivity means diversified sources and balance. Some interviewees take objectivity as a technique and/or a ritual in their coverage of conflicts. Wars and conflicts present a complex situation with two or more warring sides and different factions. Journalists cannot roam freely between the two warring sides. They obtain information from different news sources and strike a balance in their reportage in order to have a comprehensive view of the conflicts and 
to avoid being accused of speaking for either side. For instance, interviewees claim, "How to be objective and impartial, how to balance the emotions and reasons are important"; "We try to report objectively and hit a balance in the reports. The audience can't take us as a spokesperson (of either side). This is very important." In addition, objectivity is used to protect journalists and their news organizations from getting into trouble. "When the news involves the two sides of a conflict, we try not to implicate either side. We don't want to be in trouble and get burned. We pursue objectivity and balance." (Personal communication, 2012) Here objectivity is taken as a ritual that Chinese war correspondents use to protect themselves from criticisms and to stay out of trouble.

Objectivity means truth. To some interviewees, objectivity means telling the truth the journalists see rather than the whole truth or other people's version of truth. "I believe objectivity and truth are always the bottom line for journalists. The truth includes the facts I see, the stuff the editorial newsroom wants me to report, and the stuff readers want to read. I feel that readers don't want to see the truth. What they want is the truth they recognize and accept. If what you report is not the truth they agree to, they would say you are making things up. What I can do is to tell the truth I see and the truth based on my independent thinking." said Adam. Adam points out the clash of ideas among three actors: journalists, editors and the audience. The three actors during the news production and dissemination process want different versions of truth. The question is whose truth the journalists are telling. Other interviewees also point out the conflicts and tensions between journalists in the frontline and editors in the newsrooms back home. Some correspondents deliberately separate their individual roles as objective reporters from the editors and news agency's editorial and official roles. "Our job is to do objective reporting. Our reports are later edited or added with something else [by the editors]. We are forced to play some official roles. That is a matter of the press agency. It is irrelevant to the journalists. As a journalist, we just do our job and report what the thing is," said Charlie. (Personal communication, 2012) Similarly, Mike said, "I write as an observer. But editors may edit the articles based on their own thoughts or the instructions they have received from the Central Propaganda Department. Editors have their preferences and implement self-censorship." (Personal communication, 2012) The quotations here indicate that in the time of clash between frontline reporters and newsroom editors, objectivity is a value that Chinese war correspondents use to justify their news coverage and their version of the truth.

Objectivity means an unattainable norm. All interviewees point out the limitations of objectivity and they think objectivity is an unattainable norm in practice. They believe that international news coverage has its stance or bias. War coverage can only get as close as possible to objectivity and the truth. Adam said there is always hidden agenda behind every story. Objectivity and the truth are benchmarks to evaluate journalists' performances.

"I used to uphold objectivity and truth as an ultimate principle that cannot be violated. But everything has changed now. They are all deceptive. I can point out the hidden agenda behind every news report. There are also limitations of journalists' personal values. I believe objectivity and truth are always a benchmark to evaluate the journalists' performances. Journalists can make efforts to get close to it but they'll never achieve it," said Adam. (Personal communication, 2012) 
More specifically, interviewees identified various causes for the unattainability of objectivity: journalists cannot see the whole picture in the front line; they usually stay in war zones for a short time period; and lack of access to news sources. In addition, when the two sides of a war/conflict talk to journalists, both sides put themselves on the high moral ground and accuse the other side of wrongdoings. Thus Chinese war correspondents tend to focus on the civilians rather than the warring parties. Paul expressed his frustrations in trying to be objective:

"We can get the truth only when we have obtained the comprehensive information. However in the conflicts, we are unable to access some information. I become more and more suspicious of objectivity and truth. It is really difficult to be completely objective. What I can do is to try to be balanced and comprehensive. I only report what I see," said Paul. (Personal communication, 2012)

Keith shares similar opinions:

"The war zones are chaotic. It is like covering Olympic Games. A reporter on the frontline can only see one point but not the whole picture. The editor in the newsrooms can see the picture objectively and completely because he collects information from all sources that enable him to make judgment. Journalists on the frontline can only file what he sees back to the editorial room. In addition, war correspondents in China are thirsty for fame. They don't stay in the conflict zones for long." (Personal communication, 2012)

At the level of objectivity-as-a-value, the Chinese war correspondents take objectivity as a universal value and embed particular meanings in the concept of objectivity. Their narrations about objectivity such as facts, detachment, neutrality, news sources, balance and the truth more or less coincides with Schudson (2001)'s definition on objectivity. But their interpretations and understandings about objectivity based on their experiences and within China's context tend to be pragmatic. Ward claims that "objectivity is a fallible, contextbound, holistic method of testing interpretations" (Ward, 2004, p. 280). As for Chinese war correspondents, in the circumstances of inter-state conflicts outside China, they understand that absolute objectivity is an unattainable norm. They interpret objectivity as a pragmatic value and a practical ritual they can use to do war journalism in the field within their means and power, to protect themselves from criticisms, and to justify their version of the truth. This can be called the Chinese-style pragmatic objectivity. It is different from the global pragmatic objectivity that Ward calls for. Ward (2004, p. 330)'s global pragmatic objectivity “insists that journalists reject the inward looking attitudes of extreme patriotism". The Chinese-style pragmatic objectivity, on the contrary, emphasizes and promotes allegiance and patriotism. As Zhang (2013) argues, Chinese journalists are also propagandists and patriots who need to cover news from the Chinese perspective, uphold China's overseas interests, and transmit China's voice on the world stage.

\section{Objectivity-as-a-practice}

At the level of objectivity-as-a-practice, for Chinese war correspondents, objectivity is compromised due to various constraints and barriers stemming from state foreign policies, military constraints, news organizations' editorial policies and political stance, journalists' 
personal values and experiences. Many constraints are imposed on journalists in the form of self-censorship and censorship.

State foreign policies. At the state level, objectivity is compromised by state influence and China's foreign policies in international affairs. This is attributed to the state ownership of Chinese news media, which determines that international news coverage is political and war coverage reflects China's state interests and foreign policies. For instance, in the Middle East, Chinese correspondents employ different journalistic practices in their coverage of IsraelPalestine and Libya. According to the interviewees, they cover Israel and Palestine more objectively and balanced than that they do Libya.

China's current policy on the Middle East is based on its philosophy of refraining from taking sides in conflicts. Chinese approaches to the region have been re-shaped since the early 1990s by the end of the Cold War and China's increasing energy dependency in the $21^{\text {st }}$ century (Horesh, 2012). "We try to remain neutral in the Middle East conflict. In the past, during the Cold War, we sided with the Arabs against Israel. But this has changed. Today we see ourselves as friends of Israel, and at the same time we attempt to maintain friendly relations with all countries. We are friends of Israel and the Turks and the Iranians and the Arabs", said Prof. Gang Ying at the Chinese Academy of Social Sciences (Melman, 2011).

Chinese news media were generally pro-Arab and anti-Israel in the past. Since 1990s, Chinese media have held a neutral and balanced stance, and support the peace process in the Middle East. Journalists are required to report the Israel-Palestine conflicts from both sides and to avoid being accused of either pro-Israel or pro-Arab bias.

"Our reports are comparatively balanced except for the news event that involves China. For instance, when covering Chinese special envoy in the Middle East, our reports are subject to the envoy's stance. When Chinese were injured (in the bombing), our reports were subject to the attitudes of the Ministry of Foreign Affairs of China. We need to verify the facts and pay attention to the identity of the injured Chinese because many Chinese entered Israel to work illegally," said Evan. (Personal communication, 2012)

As for the Libyan conflict, China's foreign policy has traditionally centered on the nonintervention principle. Libya presented unusual challenges to China: domestic demand to ensure the safety of more than 35,000 Chinese working in the country, widespread support among Arab countries for tough action against Qaddafi, and economic interests in Libya that might be threatened by supporting the wrong side (Anonymity, 2011). To avoid a policy dilemma, China initially abstained from voting on a UN resolution that authorized international military intervention in Libya on humanitarian grounds. Then China took a step further and supported the UNSC Resolution in 1970, which placed an arms embargo, froze Libyan funds and assets, and referred the regime to the International Criminal Court. China cultivated relations with both Qaddafi's regime and the Benghazi-based rebels (Dorsey, 2012; Huang, 2012).

Against this backdrop, censorship and self-censorship were used to ensure the consistency of foreign policy and news coverage. Chinese news media were wary not to cross the red line and frontline reporters' news coverage was censored in the editorial rooms. For marketoriented media, the concept of marketization is meant to bypass the political risks. When it comes to the Libyan conflict, local market-oriented media still encountered political restrictions. In early April 2011, a team of four journalists from Southern Metropolis Daily, 
two print journalists and two photographers, sneaked into Benghazi and secretly stayed with the opposition party for one week. The Guangdong Propaganda Department and the newspaper agency banned them from entering Benghazi because the Chinese government did not recognize opposition parties at that time and the government was busy flying out its citizens on chartered flights and four military aircraft. If any journalists were injured or killed, it would have had a negative effect on the largest overseas evacuation mission in China's history. Journalists at Southern Weekend went to Libya in September 2011 and they avoided certain topics, for instance, they would not report on the relationship between China and Qaddafi's regime, whether China sold weapons to Qaddafi or not, or even the well-being of the Chinese in Libya. Their reports focused on the origin, status-quo and trends in the conflict.

Central media traditionally play a propaganda role and represent the government's voice. Reports that were deemed to be against China's foreign policies were censored and/or selfcensored before going on air.

"There was one piece in which I held a green covered book that records Qaddafi's thoughts. We took a close-up shot. I held the green book and asked the locals: do you know what it is about? What is written in the book? Young people had no ideas. This was meant to reflect the declining influence of the green book over the past decades and it also proves Qaddafi's declining influence. After this piece was transmitted back to the headquarters, editors cut it paragraph by paragraph. I did not see the final piece because I would feel heart-broken. When the concepts of state media and the state, institution and government are integrated in China, editors and audiences think that we represent the voices of the government. For me, I won't emphasize the government's stand. I'll try to avoid the influence caused by those negative factors," said Ray. (Personal communication, 2012)

This quotation clearly indicates the conformity between state foreign policy on Libya and the editorial principles in the newsroom in Beijing. It also demonstrates the power struggle and the conflict of interests among the state, the newsrooms and frontline journalists. The state has the greatest power and it uses the news media to facilitate its foreign polices by directly or indirectly influencing the editorial decisions in newsrooms via censorship and/or selfcensorship. Journalists may pursue objectivity and professional ethics but they are at the bottom of the hierarchy of power. Hence they tactically negotiate their roles in the power struggle and deal with state constraints by ignoring the administrative orders, covering nontaboo topics, and refusing to read or watch the edited news pieces as a form of protest.

Military constraints. Objectivity is also compromised by access restrictions and military censorship imposed through the pool and embedding systems. As for the pool system, Evan who was based in Israel said Chinese journalists encounter access restrictions to the "pool" due to their possession of less prestige compared to the big names in the West such as the AP (Associated Press) or CNN.

"For some news, we can only enter the pool organized by Israeli Association of Foreign Correspondents to do interviews. This pool is only open to the Western media. It is very difficult for Chinese journalists to join. Of course we may not have worked hard enough and there may be some historical reasons. We need to maintain good relations with the Association for years and then they may slowly accept us. They certainly think we are not as important as AP or CNN," said Evan. (Personal communication, 2012) 
As for the embedding system, two journalists were embedded with the 101st Airborne Division of the American military in Kandahar, Afghanistan in 2010 and they witnessed missions of rooting out Taliban militants. They feel their actions were highly restricted and they were in a catch- 22 .

"The embedding system of American militaries is fully developed. We have very limited autonomy. Americans signed contracts with us and set down rules and regulations...I feel it is particularly difficult to do independent reports while being with the American militaries. We feel that we can say anything but actually we cannot. For example, apart from the clauses set out in the contract, the press officer will often come to talk to us and convince us not to file certain reports. They would say if we file that news report, the soldiers we stay with day in and day out would face penalty and get demoted. They seem to give us the freedom to do reporting but the restrictions are huge. Someone is always monitoring our news coverage," said Bob. (Personal communication, 2012)

In Afghanistan, post censorship was imposed on the embedded journalists. According to the interviewee, the American military embedded Chinese journalists with American soldiers to propagate their attacks against Taliban. If the news reports were found out not to be what the military wanted, the journalists were thrown out.

"In Afghanistan, post censorship was imposed. They invited us to help them propagate their operations. If they found our reports were not what they needed, they would stop providing any assistance. For example, after doing interviews for two weeks with one battalion, we planned to extend our stay for another week and to embed with another battalion. But the identity of an informant was accidentally exposed on our English newspaper's website. According to the rules, we were not allowed to cover the intelligence activities in the field. However, we got permissions from the field commanders to do interviews. All our interviews were approved. The problem was not ours but theirs," said Charlie. (Personal communication, 2012)

It is a big step forward that Chinese journalists have joined the pool and embedding systems to obtain first-hand information as their Western counterparts do. However since the military provides supplies and protection, journalists encounter access restrictions, movement restrictions, and censorship. This, in effect, compromises journalists' objective reporting.

Editorial policies. At the corporate level, objectivity is compromised by news organizations' political stance, editorial policies and procedures, and audience demands. In China, rightwing politicians and intellectuals are viewed as liberals whereas left-wing politicians and intellectuals are viewed as conservatives (Lu, 2012). "Liberals, not the government, play the dominant role in the domestic public opinion", said Adam. Since the reform era of the 1980s, liberals and conservatives are two opposing political factions. Liberals champion democracy, freedom and human rights and call for democratic politics whereas conservatives insist on orthodox ideology and call for strict control over social life (Xiao, 2005).

In the Libyan conflict, "liberals are pro-West who worship Western freedom and think Qaddafi's government was a dictatorship. Conservatives believe that China was on good terms with Qaddafi's Libya and the Western countries stirred the uprisings," said Ray. (Personal communication, 2012) Although all news media is state owned, different news organizations have different political orientations, which are reflected in the editorial policies and journalists' ideology and practices. 
CCTV is China's only state television station and it claims to be "China's important news and public opinion organization; the tongue and throat of the Party, the government and the people; a significant ideological and cultural battlefield; and one of the most competitive mainstream media." (CCTV website, 2009). Ray believes he presented both liberal and conservative views in his Libyan coverage.

"When I reported that Qaddafi came out and accused the NATO of killing innocent people, right-wing criticized that I was the spokesman of Qaddafi government. In our news reports in Libya, we presented both liberal and conservative views. We reported everything within two months," said Ray. (Personal communication, 2012)

Global Times is an influential, profitable and elite newspaper affiliated to People's Daily and "arguably the most important institution for the expression of quasi- or semi-official foreign policy positions" (Lee, 2010, p. 265). The title was accused to "be the Global Times run by Mubarak during the uprising in Egypt; the Global Times run by Saddam during the US strike on Iraq; and the Global Times run by Qaddafi during the Libyan conflict." (Feng, 2012). One interviewee confirmed the paper's pro-Qaddafi line. "We must cover news from China's standpoint. In Libya, I was told China's stand was to support Qaddafi. We can't say Qaddafi was wrong as the Western media did. We can't side with Western journalists." said Daniel. (Personal communication, 2012)

Southern Metropolis Daily is a liberal paper in China and the newspaper's stance of prorebels in Libya was crystal clear in the interviewee's comments.

"We are liberal media and we sympathize with the oppositions. We interviewed an opposition military spokesman who was angry and he said: 'We will wait for China to express its attitude till the last minute of the war'. We explained to him that we are not propaganda but liberal media and we can express our own views," said Oliver. (Personal communication, 2012)

The comparison of CCTV, Global Times and Southern Metropolitan Daily demonstrates that although all the news media in China must toe the Party/state line, each has its own editorial policies that align with the domestic political and intellectual factions, either liberals or conservatives, and public opinion. Journalists cover the conflicts in compliance with editorial policies, willingly or unwillingly, which leads to political bias in their reports and thus compromises objectivity.

Personal values. At the individual level, objectivity is compromised by journalists' personal feelings, values and experiences. Journalists agree that for any news article, $30 \%$ of content is based on journalists' personal feelings and political stance, and $70 \%$ of is based on facts. They try to be objective and put personal feelings and values aside.

Evelyn was a resident correspondent based in Israel for two years. She said:

"There may be emotional factors (in my reports). After all, I lived in Israel and I was affectionate towards Israeli people and the environment. It was not that I deliberately beautify Israel. I was simply able to write and make judgment about Israel in a more comprehensive manner because I have better understanding about the country." (Personal communication, 2012) 
Bob insists that he reports from two sides and he tries not to let his personal feelings get in the way in his reportage. He said:

"I surely write about the two sides. After having been to Syria three times, personally, I believe Bashar regime is the most democratic under the current political system in the Middle East. In this sense, I sympathize with him. But sympathy can't replace the facts. His regime was opposed by so many people who want to topple him at the cost of their lives. It can be traced back to his father's era. There are too many problems accumulated over the years. It determines that Bashar's efforts are not sufficient to balance people's hatred and external pushing force. The external force is not that the European countries and America want to topple Bashar regime but the fact that people in Arab world demand for reforms. The trend is irresistible. So we need to reflect this trend. My personal feelings are not directly related to what I write." (Personal communication, 2012)

These quotes reveal that Chinese journalists understand the personal bias in their news reports while covering complex conflicts such as Israel-Palestine and Syria. In practice, they try to disengage their emotions, personal views and values from the facts and cover the conflicts in a fair and comprehensive manner.

\section{Conclusion}

Today many Chinese journalists and educators find inspiration in the Anglo-American liberal model, and market-oriented media outlets proclaim objectivity and impartiality in their news reporting without rejecting their CCP-mandated role of maintaining the "correct orientation to public opinion" (Zhao, 2012, pp. 163-5). Chinese journalists construct and localize objectivity through their improvised and situated practices. They invoke and deploy different professional norms and different, even contradictory, facets of what Hackett and Zhao (1998) described as the "regime of objectivity" in accordance with their own ideological framework (ibid). Within this objectivity regime, Chinese-style pragmatic objectivity addresses how Chinese war correspondents perceive the concept and the constraints and barriers that compromise objectivity when they cover regional conflicts overseas.

Chinese-style pragmatic objectivity is a convenient approach for Chinese journalists who do war journalism in the field. At the level of objectivity-as-a-value, objectivity is defined as a universal value and journalistic normative ideal referring to facts, detachment, neutrality, diversified news sources, balance and the truth. Ward's pragmatic objectivity is similar to the traditional objectivity in stressing factuality and fairness but it is "testing of interpretations" and it allows "varying degrees of detachment in different circumstances" (Ward, 2004, p. 22).

Chinese journalists use objectivity as a pragmatic value and a practical ritual to do war journalism with the resources and power available to them, to protect themselves from criticism, and to justify their version of truth. Rather than rejecting the inward looking attitudes of patriotism, the Chinese-style pragmatic objectivity promotes allegiance and patriotism in terms of covering news from the Chinese perspectives, upholding China's overseas interests, and transmitting China's voice on the world stage.

At the level of objectivity-as-a-practice, Chinese style-pragmatic objectivity means that Chinese journalists perceive absolute objectivity and/or absolute truth as unattainable norms 
in the conflicts. This conforms with Ward's pragmatic objectivity theory in that "the standards of objectivity are means to truth, not truth itself. Pragmatic inquiry is a truth oriented process that is fallible, situated, and pluralistic yet non-arbitrary" (Ward, 2004, pp. 268-9). For Chinese journalists, objectivity in war coverage is fallible, which is compromised by various constraints and barriers including, but not limited to, state foreign policies, military constraints (access restrictions, pool and embedding systems), political orientations and editorial polices of news organizations (liberals or conservatives), editorial procedures (censorship and self-censorship), and journalists' personal experiences and values. The authoritarian political and press system in China determines that media discourses have to conform to official discourses, and alternative voices have to conform to mainstream voices. There is often a clash of ideas between journalists in the frontline and the editors in the newsrooms. Journalists use Chinese-style objectivity to negotiate their roles in the power struggle with the state, the foreign military, the newsroom and journalists. After all, journalists use the term of objectivity as part of a method, part of a ritual, and part of an ideal, all of which is conditioned by nationality, news institution and markets.

This paper has discussed Chinese journalists' perception, working practices and operationalization of objectivity in war reporting. The author recognizes that there is a gap between journalists' perceptions towards objectivity and the applications of objectivity in practices, between what journalists' claim they do and what they actually do. In the future, a systematic textual analysis, e.g. content analysis and/or critical discourse analysis, can be done to shed light on how the Chinese news media actually present and frame regional wars and conflicts around the world. That will be a new and interesting dimension to study Chinese wartime journalism and the concept of objectivity.

\section{References:}

Aday, S., Livingston, S. \& Hebert, M. (2005). Embedding the Truth: A Cross-Cultural Analysis of Objectivity and Television Coverage of the Iraq War. The International Journal of Press/Politics, vol. 10 no. 1, 3-21

Anonymity (2011). A rising power starts to knock against the limits of its hallowed "noninterference. The Economist, September 10. Retrieved May 9, 2012, from http://www.economist.com.hk/node/21528664

Chinese war correspondents released their first book. Global Times, January 4, 2011. Retrieved May 1, 2012, from http://news.cultural-china.com/20110104123744.html

De Burgh, H. (2005). Making journalists: diverse models, global issues. London: Routledge

Anderson, F. \& Trembath, R. (2011). Witnesses to War: The History of Australian Conflict Reporting. Melbourne: Melbourne University Publishing

Bennett, W. L. (2003). News: the politics of illusion. Fifth edition. Addison Wesley Longman, Inc.

Berenger, R. D. (2005). Al Jazeera: In Pursuit of 'Contextual Objectivity. Transnational

Broadcasting Studies, 14, Spring. Retrieved June 17, 2013, from

http://www.tbsjournal.com/ReviewsBerenger.html 
Berry, S. J. (2005). Why Objectivity Still Matters. Nieman Reports. Retrieved March 11, 2014, from http://www.nieman.harvard.edu/reports/article/101090/Why-ObjectivityStill-Matters.aspx

Boudana, S. (2010). On the values guiding the French practice of journalism: Interviews with thirteen war correspondents. Journalism, 11(3):293-310

Boudana, S. (2011). A definition of journalistic objectivity as a performance. Media Culture Society, 33: 385

Campbell, L. \& Wolseley, R. (1961). How to Report and Write the News, Englewood Cliffs: Prentice Hall

Carpentier, N. \& Trioen, M. (2010). The particularity of objectivity: A post-structuralist and psychoanalytical reading of the gap between objectivity-as-a-value and objectivity-as-apractice in the 2003 Iraqi War coverage. Journalism, 11(3), 311-328

CCTV website (2009). Introduction to China Central Television Station. 17 June. Retrieved June 21, 2013, from http://cctvenchiridion.cctv.com/20090617/113152.shtml

Deuze, M. (2005). What is journalism? Professional identity and ideology of journalists reconsidered. Journalism, vol. 6 no. 4, 442-464

Dorsey, James M. (2012). China Needs to Change its Middle East Foreign Policy. Fair Observer, February 14. Retrieved May 6, 2012, from http://www.fairobserver.com/article/china-needs-change-its-middle-east-foreign-policy

El-Nawawy, M. \& Iskandar, A. (2002). The Minotaur of "Contextual Objectivity": War coverage and the pursuit of accuracy with appeal. Transnational Broadcasting Studies, No. 9, Fall/Winter. Retrieved June 17, 2013, from http://www.tbsjournal.com/Archives/Fall02/Iskandar.html

Fahmy, S. \& Johnson, T. J. (2005). How we reported: embedded journalists' attitudes and perceptions towards covering the Iraq war. Journalism and Mass Communication Quarterly, 82/2, 301-307

Gans, H. (1979). Deciding What's News: A Study of CBS Evening News, NBC Nightly News, Illinois: Northwestern University Press

Hackett, R. A. (1984) Decline of a paradigm? Bias and objectivity in News Media Studies. Critical studies in Mass Communication , 1(3), 229-259

Hackett, R. A. \& Zhao, Y. (1998). Sustaining Democracy? Journalism and the politics of objectivity, Toronto: Garamond

Hadland, A. and Zhang, S.I. (2012). The "paradox of commercialization" and its impact on media-state relations in China and South Africa, Chinese Journal of Communication, Volume 5, No. 3, 316-335 
Hampton, M. (2008). The 'objectivity' ideal and its limitations in $20^{\text {th }}$ century British journalism, Journalism Studies, 9:4, 477-493

Harris, J., et al (1981). The Complete Reporter, 4th edn. New York: Macmillan.

Horesh, N. (2012). China's relations with the Middle East, in Kavalski, E., ed. The Ashgate research companion to Chinese foreign policy, Surrey: Ashgate, pp.223-236

Huang, C. (2012). China and peacekeeping operations, in Kavalski, E, ed. The Ashgate research companion to Chinese foreign policy, Surrey: Ashgate, pp.337-348

Iskandar, A. and El-Nawawy, M. (2004). Al-jazeera and war coverage in Iraq: the media's quest for contextual objectivity, in Alan, S. and Zelizer, B. (eds.) Reporting war: journalism in wartime, New York: Routledge, pp.315-332

Iskankar, A. (2005). The Great American Bubble Fox News Channel the Mirage of Objectivity and the Isolation of American Public Opinion, in Artz, L. \& Kamalipour, Y. R. (eds.) Bring 'em On: Media And Politics In The Iraq War, USA: Rowman \& Littlefield

Kellner, D. (2008). War correspondents, the military and propaganda: some critical reflections, International Journal of Communication, Vol. 2, 297-330

Knightley, P. (2002). The first casualty: The War Correspondent as Hero and Myth-Maker from the Crimea to Kosovo, Baltimore: The Johns Hopkins University Press

Liang, L. (2011). Going live: news innovations amid constraints in the Chinese coverage of the Iraq War, Journalism, 13(4), 450-66

Lu, X. (2012). A Burkean analysis of China Is Not Happy: a rhetoric of nationalism, Chinese Journal of Communication, 5:2, 194-209

Mancini, P. (2000). Political complexity and alternative models of journalism: the Italian case, in Curran, J. \& Park, M. (eds.) De-westernizing media studies, New York: Routledge, pp. $265-278$

McBride, S. (1980). Many Voices, One World, London: UNESCO

McLaughlin, G. (2002). The war correspondent, London: Pluto Press

McNair, B. (2013). Trust, truth and objectivity: sustaining quality journalism in the era of the content-generating user, in Peters, C. \& Broersma, M, eds. Rethinking journalism: trust and participation in a transformed news landscape, London: Routledge 
Melman, Y. (2011). China will not stop Israel if it decides to attack Iran, September 22, Haaretz. Retrieved May 8, 2012, from http://www.haaretz.com/printedition/features/china-will-not-stop-israel-if-it-decides-to-attack-iran-1.385950

Mo, S. (2011). Chinese war correspondents in Libya, Bund Pictorial (Waitan Huabao), Issue 453, September 1. Retrieved May 8, 2012, from http://www.bundpic.com/2011/08/15700.shtml

Muñoz-Torres, J. R. (2012). Truth and objectivity in journalism, Journalism Studies, 13:4, 566-582

Pan, Z. \& Chan, J. M. (2003). Shifting Journalistic Paradigms: How China's Journalists Assess "Media Exemplars", Communication Research, 30: 649

Pan, Z. \& Lu, Y. (2003). Localizing professionalism: discursive practices in China's media reforms, in Lee, Chin-chuan, ed. Chinese media, global contexts, London: Routledge

Polumbaum, J. (2008). China ink: the changing face of Chinese journalism, New York: Roman \& Littlefield Publishers Inc.

Ryan, M. (2001). Journalistic ethics, objectivity, existential journalism, standpoint epistemology, and public journalism, Journal of Mass Media Ethics, 16 (1), 3-22

Schudson, M. (1978). Discovering the News: a social history of American newspapers, New York: Basic Books

Schudson, M. (2001). The Objectivity Norm in American Journalism. Journalism, Vol. 2(2), $149-170$

Schudson, M. (2003). The sociology of news, New York: W.W. Norton \& Company, Inc.

Spencer, G. (2005). The media and peace: from Vietnam to the 'War on Terror', London: Palgrave Macmillan

Tuchman, G.(1978). Making news: a study in the construction of reality, New York: The Free Press

Tumber, H. \& Prentoulis, M. (2003). Journalists under fire: subcultures, objectivity and emotional literacy, in Thussu, D. K. \& Freedman, D. (eds). War and the media, London: Sage Publications

Tumber, H. \& Wester, F. (2006). Journalists under fire: information war and journalistic pdractices, London: Sage Publications

Ward, S. J. (1998). An answer to Martin Bell: objectivity and attachment in journalism. Harvard International Journal of Press/Politics, 3, 3: 121-5

Ward, S. J.A. (2004). Invention of Journalism Ethics: The Path to Objectivity and Beyond, Canada: McGill-Queen's Press

Williams, K. (2011). International journalism, London: Sage 
Wu, W. (2000). Motives of Chinese Students to Choose Journalism Careers. Journalism \& Mass Communication Educator, 55: 53

Xiao, G. (2005). Liberals and conservatives since China's reform and opening up (Zhongguo gaige kaifang yilai zhengzhi zhong de ziyoupai he baoshoupai). Retrieved June 21, 2013, from http://www.aisixiang.com/data/6771.html?page=1

Zhang, S. I. (2013). The new breed of Chinese war correspondents: their motivations, roles and impact of digital technology. Media, War and Conflict, 6 (3), 311-325

Zhao, X. (2007). On war correspondents (Zhandi jizhe shulun), Beijing: Zhongguo Guangbo dianshi chubanshe

Zhao, Y. (2012). Understanding China's media system in a world historical context, in Hallin, D. C. \& Mancini, P. (eds.) Comparing media systems beyond the Western world, Cambridge: Cambridge University Press 